\title{
Public policies, social perception and media content on fracking: An analysis in the Spanish context
}

\author{
EMILIA HERMELINDA LOPERA-PAREJA \\ Centro de Investigaciones Energéticas, Medioambientales y Tecnológicas (CIEMAT) \\ emilia.lopera@ciemat.es \\ ANA GARCÍA-LASO \\ DOMINGO ALFONSO MARTÍN-SÁNCHEZ \\ Polytechnic University of Madrid \\ ana.garcia.laso@upm.es \\ domingoalfonso.martin@upm.es
}

\begin{abstract}
Energy supply and security is a topic that connects geoscience and ethics to economic, social and sustainable development. It also involves a wide range of interests and social actors, such as politicians, experts, industry, environmental NGO and citizen organizations and platforms. The fossil fuel extraction industry using hydraulic fracturing, and commonly known as fracking, is one of the most recent and controversial issues arising from the application of energy technologies in North America, South America and Europe. This paper examines the public debate in Spain on the topic of fracking from a multi-level and complementary perspective, based on data collected during 2012-2016 by exploring the development of public policies at national and regional levels, monitoring public perception through a survey, and analyzing the media content. From the theoretical frameworks of social amplification of risk and post-materialist values, a content analysis was applied to assess the relevance and the social, cultural and human values distributed by the press when dealing with fracking in Spain.

Our results concerning public policies show that there are different positions on the matter between national and regional authorities, even if both authorities belong to the same political party. Regarding social perception, almost 60 per cent of Spaniards have admitted to having no opinion about fracking. Finally, media discourse has been driven by pessimistic views, focused mainly on cost-benefit analysis and emphasizing how human health, natural resources and local communities might be negatively affected by fracking activities.
\end{abstract}

\section{INTRODUCTION}

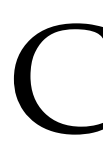

urrently hydraulic fracturing techniques to extract fossil resources often do not meet with general social acceptability. The implementation of fracking has aroused public opposition in many local communities, becoming a controversial issue both in the United States and in European countries due to its potential consequences on the environment and human health (Jaspal and Nerlich, 2014; Negro, 2012).
In addition to economic and technical feasibility, the lack of public acceptance emerges as a complementary research field. In this context, this contribution examines the development of public policies, social perception and media discourse on fracking in Spain with the aim to understand the dynamics and synergies that may be influencing the emergence and evolution of public opposition and the potential underlying ethical implications.

For this purpose different sources and data were used: a) following and monitoring of public policies related to the topic at national 
and regional level from 2012 to 2016; b) data collected from the national survey on social perception of science and technology conducted in 2014 by the Spanish Foundation for Science and Technology; and c) data resulting from a content analysis applied to the press coverage on fracking published by the premium general information newspaper in Spain, El País, during the timeframe 2013 and 2014.

\section{RESULTS}

\section{Public policies}

Spanish public policies on energy issues have experienced great changes since 2012 in updating and adapting the national regulatory framework in order to speed up and promote the implementation of fracking extractive technique. The sustained increase of oil prices from 2009 to 2014 and, as a consequence, the interest shown by fossil fuel companies to explore and exploit shale gas fields in several areas of the Spanish territory were some of the key factors behind legal reforms developed by the national conservative Government. At the same time, public policies on renewable energies also experienced significant changes following the entry into force of the Decree Law $1 / 2012$ on the abolition of the subsidies to renewable energies (Official State Gazette, 2012). Hydraulic fracturing was expressly included among the standard technologies for the exploitation of unconventional shale gas in Spain under the Law 17/2013 on the security of energy supply (Official State Gazette, 2013a), amending Law 34/1998 on hydrocarbons (Official State Gazette, 1998). The environmental impact assessment for fracking projects was also included in Law 21/2013 (Official State Gazette, 2013b), although preliminary projects to study viability through this technique were exempt.

Whereas licenses for exploration activities are granted by regional authorities when the whole area is located in a single region, this responsibility falls to the national authorities when the activity covers two or more regions. Given this regulatory situation, three of the Spanish northern regions - Cantabria, La Rioja and Navarra - were adopting respective regional laws on the ban of fracking activities in its territories throughout 2013. But the national Government immediately appealed these laws to the Spanish Constitutional Court.

At the European level, in January 2014 the European Commission published a set of recommendations $(2014 / 70 / \mathrm{EU})$ on minimum principles for the exploration and production of hydrocarbons using high-volume hydraulic fracturing (Official Journal of the European Union, 2014). But instead of setting a common framework, Member States were simply 'invited to' plan developments, assess environmental impacts, ensure the best practice standards, check the quality of the local water, air and soil, control air emissions and inform the public. Some months later, the three regional laws banning fracking were repealed by the Constitutional Court. The respective rulings were based on the existence of a conflict of political and administrative competences between regional and national authorities in the field of exploratory drilling and extraction of no conventional hydrocarbons. Since hydrocarbon resources are deemed strategic, the regulation falls within the competence of national authorities.

Unlike in the United States, Spanish landowners do not have property rights over the exploitation of fossil fuels from the subsoil. In fact, according to the aforementioned hydrocarbon law, gas and oil fields are considered strategic resources of state public domain. However, the strong opposition against fracking expressed by local and regional authorities plus the public rejection and protest movement promoted by local platforms on social networks and in the streets could have motivated the adoption of a new national regulation in 2015 that provided for economic benefits for individuals, local, and regional authorities.

In fact, in order to further promote the use of fracking despite the controversial social debate at the local level, the new Law 8/2015 called for a system of financial compensation and incentive for property owners, municipalities, and regions (Official State Gazette, 2015); in this latter case through taxes and fees paid by 
the operating industry. But the promise of economic benefits did not prevent Catalonia and the Basque Country from banning fracking in their territories over the course of 2015. At present, these laws await a ruling by the Spanish Constitutional Court.

Disagreement over fracking was also a reason for the confrontation between regional and national political leaders, especially within the right-wing party, Partido Popular. Generally, local and regional institutions geographically closer to the citizen daily life shared the same view against fracking including worries about possible negative effects derived from such energy facilities. The opposition to fracking shown by the conservative regional government of La Rioja is a paradigmatic example of this situation.

\section{Social perception and public interest}

The last edition of the Spanish survey on social perception regarding science and technology (FECYT, 2015) featured two new questions about the consequences of scientific and technological development in general (Q.14) and about specific technological applications (Q.15) such as hydraulic fracturing and nuclear energy (Muñoz-van den Eynde, 2015). According to the results, almost 60 per cent of the respondents admitted they did not have an opinion on fracking whereas only 9 per cent reported the same answer regarding nuclear energy, a much more controversial issue in Spain and abroad for a much longer time. From the remaining 40 per cent of respondents with an opinion on fracking, 24 per cent considered that it represented higher risks than benefits whereas 7 per cent believed the opposite. Finally, for 10 per cent of the interviewers risks and benefits were balanced (Fig. 1).

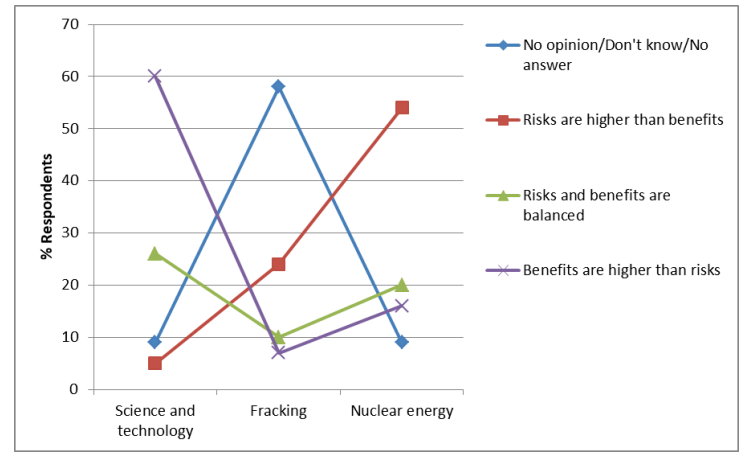

Figure 1: Social perception on technological applications, fracking and nuclear energy in Spain. Data source: Muñoz-van den Eynde (2015).

The fact that six out ten Spaniards do not have an opinion on fracking should not be interpreted as a lack of concern or interest to know more about this matter. As in a previous study analyzing the fracking debate in the United States and United Kingdom (Mazur, 2016), we used the monthly frequency of web searches on "fracking" as reported by Google Trends as a measure of public interest (filtering on Spain), along with media trends in the time period of 2013 and 2014. Google Trends and El País media attention is shown in Fig. 2 using normalized data, that is, adjusted so that the month with the higher web searches and articles were indexed as 100, and numbers of searchers and articles for other months are a proportion of that number. This is an effective strategy to compare public and media interests on a similar issue. Data represented in Fig. 2 show that while media attention suffered great fluctuations during the period in question, the public interest remained more stable and increased on December 2014. Accordingly, it could be interpreted that in some manner media attention boosted public interest during 2013 although public interest on fracking remained active and even surpassed media attention for most of the year 2014. By regions, web searches on fracking were much more frequent in northern regions of Spain more affected by exploratory efforts and where local authorities tried to ban this activity: Cantabria, Basque Country, La Rioja and Navarra. Concern, public opposition and confrontations be- 
tween regional and national Governments could have made the issue more salient for online users from these communities.

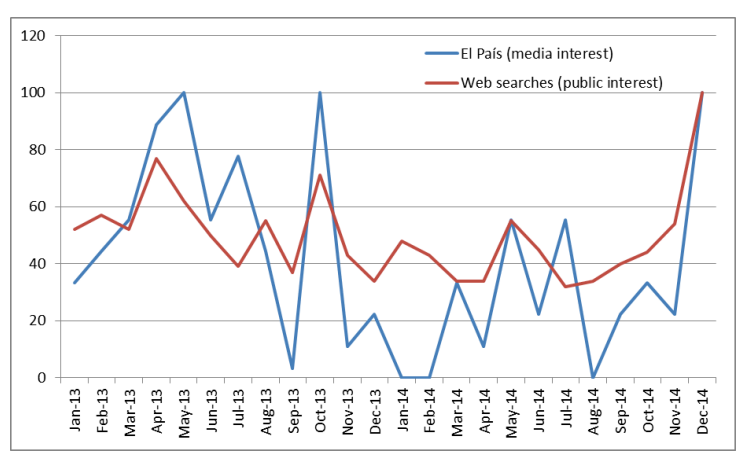

Figure 2: Spain web searched on "fracking" and reporting in El País, 2013-2014.

\section{Media content}

On a quarterly basis (Fig. 3), our results reveal that the tone of media discourse evolved from a perspective mainly dominated by pessimism concerning the viability of fracking in 2013 representing the technique as a threat rather than as an alternative source of energy and prosperity - to an increase of news stories written from a neutral view in 2014. Optimistic approaches supporting the implementation of this type of extraction were clearly scant throughout the studied timeframe.

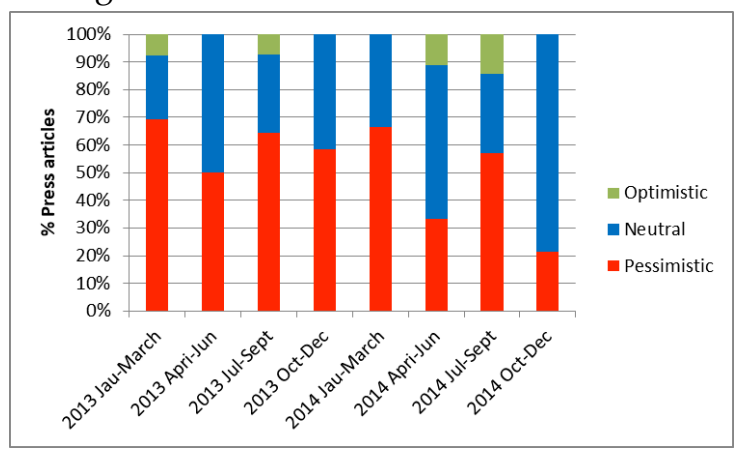

Figure 3: Tone of media discourse (El País) on fracking in Spain, 2013-2014.

In order to have a comprehensive understanding of how pessimistic and optimistic views about fracking were constructed in the Spanish press coverage we applied a content analysis (data collection, sampling and complete list of variables are available in: Lopera et al., 2015) whose risk and benefit variables were inspired by the sociological theory of post-materialism (Inglehart, 2008). According to this theoretical framework it is assumed that Western societies have been gradually switching from the acceptance of material values (calculated as benefit variables) to the defense of post-materialist values (calculated as risk variables) (Table 1).

Table 1: Categories and subcategories of the variables coded in the content analysis applied to the press coverage on fracking.

\begin{tabular}{|l|l|l|}
\hline \multirow{4}{*}{$\begin{array}{l}\text { Risk } \\
\text { variables } \\
\text { (worries) }\end{array}$} & Environment & Woil \\
& & Air quality \\
\cline { 2 - 3 } & Human health \\
\cline { 2 - 3 } $\begin{array}{l}\text { Benefit } \\
\text { variables } \\
\text { (promises) }\end{array}$ & Enduced seismic activity \\
\cline { 2 - 3 } & Economy & $\begin{array}{l}\text { Job } \\
\text { opportunities }\end{array}$ \\
\cline { 2 - 3 } & Energy supply and security \\
\hline
\end{tabular}

Post-materialism emphasizes non-material goods focusing on a clean and healthy environment instead of materialism positions that argue that economic growth is strongly articulated with energy security and supply.

Fig. 4 shows a quantitative snapshot of fracking social representation through the daily press in Spain in terms of risks and benefits. Our findings revealed that media content primarily highlighted certain endangered postmaterialist values, mainly focused on negative impacts on human health (51 per cent of the news articles) and several environmental aspects at a local scale such as water resources (groundwater) (49 per cent). To a lesser degree soil (23 per cent) and air quality (17 per cent) were shown to be under risk as well.

Possible induced seismic activity was also a narrative element taken into account by the news media (16 per cent). The connection between seismic movements and fracking was not only based on describing the tremors that 
have occurred abroad (Lancashire, in UK, and Oklahoma, in USA) (El País, 2013a; El País, 2013b), but also those in Spain along the Mediterranean coast, in Valencia region (El País, 2014). The occurrence of several earthquakes, with magnitude ( $\mathrm{M}$ between 3.8 to 4.3 ) (Juanes et al., 2017), forced the closure of a megaproject that was supposed to store injected natural gas using the old facilities of an oil exploitation in Amposta, known as the Castor Project. The New York Times made a connection between potential impacts of fracking and the severe consequences of the British Petroleum oil spill in the Gulf of Mexico on April 2010 (Mazur, 2016), whereas in Spain El País connected the tremors occurred due to the gas storage of the Castor Project in 2013 to the potential impacts of induced seismic activity resulting from fracking activities.

On the other hand, materialist values were highlighted as key narrative elements in the articles offering a neutral and/or optimistic approach, especially the economic benefits (39 per cent) and energy security and supply (30 per cent). We stress that whereas these benefits were depicted at a national scale in a very diffuse way, the aforementioned risks were represented as a close threat for local and traditional lifestyles based on agriculture, livestock and tourism. This results fall in line with the data obtained by Davis and Fisk (2014) when analyzing public attitudes toward fracking use and policies in the USA. Previous studies analyzing representations of fracking on YouTube videos from a cost and benefits angle identified threats to environmental, human and economic values (Jaspal et al., 2014). Social and psychological impacts on small communities were highlighted as well.

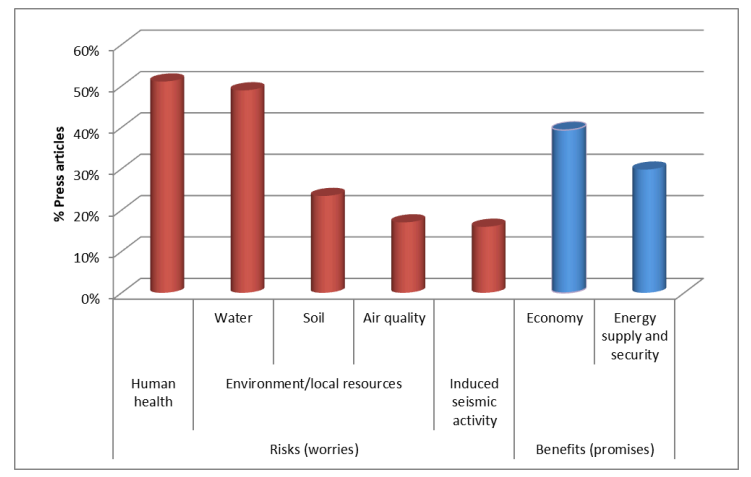

Figure 4: Risks and benefits of implementing fracking according to the media content.

\section{CONCLUSIONS}

This paper reveals that the prevailing media discourse on the use of fracking in Spain has been pessimistic and neutral, almost always underlining the potential negative impacts on human health, environment and local natural resources rather than as an exclusive energy issue providing economic growth arising from energy security and supply. This was combined with the lack of a clear public opinion at a national level despite strong local opposition in the affected regions. Moreover, the analysis and monitoring of the public policies on this issue indicate a deep confrontation between national and regional Governments, especially controversial in those regions where exploration studies have been completed or are being planned in order to study the economic and technical viability of the fracking projects: Cantabria, La Rioja, Navarra, Catalonia and Basque Country, among others. While national policies are designed to promote the implementation of fracking attending to the industry claims, the main goal of regional policies was to avoid the use of fracking in their territories. In this regard, local and regional authorities showed to be more sensitive and receptive to the instances of the public opposition than the directives of the national Government.

\section{ACKNOWLEDGMENT}

This work was carried out as part of the project "Concept and dimensions of scientific culture" (MINECO-15-FFI2014-58269-P) funded by the Spanish Ministry of Economy and Competi- 
tiveness and by the Department of Economy and Employment of the Principality of Asturias for the "Grupo de Estudios CTS" (FC-15GRUPIN14-128).

\section{REFERENCES}

Davis, C., and Fisk, J.M. (2014). Energy abundance or environmental worries? Analizing public support for fracking in the United States, Review of Policy Research, 31(1), 116.

El País (2013a). El 'fracking' atrae réplicas de terremotos lejanos $(7 / 12 / 2013)$. Available from: https: / / elpais.com/sociedad/2013/07/ 12/actualidad/1373660760_579342.html (accessed 2 October 2017).

El País (2013b). Terremotos fruto de la actividad humana $(3 / 27 / 2013)$. Available from: https:/ / elpais.com/sociedad/2013/03/ 27/actualidad/1364419029_235833.html (accessed 2 October 2017).

El País (2014). Los expertos confirman la relación entre los seísmos y el proyecto de gas Castor (5/12/2014). Available from: https: / / elpais.com/sociedad/2014/05/12/ actualidad/1399897547_384101.html (accessed 2 October 2017).

FECYT (2015). Cuestionario de la VII encuesta de percepción social de la ciencia y la tecnología en España, Percepción Social de la Ciencia y la Tecnología 2014, Madrid, FECYT, 365-396. Available from: https:/ / icono.fecyt.es/sites/default/files/filepu blicaciones/cuestionario_epscyt204.pdf (accessed 2 October 2017).

Inglehart, R. (2008). Changing values among western publics from 1970 to 2006, West European Politics, 31(1-2), 130-146.

Jaspal, R., and Nerlich, B. (2014). Fracking in the UK press: Threat dynamics in an unfolding debate, Public Understanding of Science, 23(3), 348-363.

Jaspal, R., Turner, A., and Nerlich, B. (2014). Fracking on YouTube: Exploring risks, benefits and human values, Environmental Values, 23(5), 501-527.

Juanes et al. (2017). Coupled flow and geomechanical modeling, and assessment of induced seismicity, at the Castor underground gas storage project. Assessment of Induced Seismicity at the Castor Project Final Report, April 2017. Available from: http: / / www.minetad.gob.es/eses/gabineteprensa/notasprensa/2017 / doc uments / castor_final_report_final_signed.p df (accessed 2 October 2017).

Lopera-Pareja, E. H., García-Laso, A., and Martín-Sánchez, D. A. (2015). Discourses and values underpin public debate on fracking in Spain: a case study at the crossroad, Geoethics for society: general aspects and case studies in geosciences - European General Union 2015 General Assembly, Vienna.

Mazur, A. (2016). How did the fracking controversy emerge in the period 2010-2012?, Public Understanding of Science, 25(2), 207-222.

Muñoz-van den Eynde, A. (2015). Factores que contribuyen a construir la imagen pública de la ciencia. La relación entre percepción, interés y conocimiento, Percepción Social de la Ciencia y la Tecnología 2014, Madrid, FECYT, 15-44.

Negro, S.E. (2012). Fracking wars: Federal, state and local conflicts over the regulation of natural gas activities, Zoning and Planning Law Report, 35(2), 1-16.

Official Journal of the European Union (2014). Recommendations 2014/70/EU on minimum principles for the exploration and production of hydrocarbons (such as shale gas) using high-volume hydraulic fracturing. Available from: http://eurlex.europa.eu/legal-content/EN/ TXT/PDF/?uri=CELEX:32014H0070\&from=ES (accessed 2 October 2017).

Official State Gazette (1998). Law 34/1998 on hydrocarbons. Available from: https:/ / www.boe.es/boe/dias/1998/10/08/pd fs / A33517-33549.pdf (accessed 2 October 2017).

Official State Gazette (2012). Decree Law $1 / 2012$ on the abolition of the subsidies to renewable energies. Available from: https:/ / www.boe.es/boe/dias/2012/01/28/pdfs /BOE-A-2012-1310.pdf (accessed 2 October 2017).

Official State Gazette (2013a). Law 17/ 2013 on the security of energy supply. Available from: https:/ / www.boe.es/boe/dias/2013/10/30/pd fs/BOE-A-2013-11332.pdf (accessed 2 October 2017).

Official State Gazette (2013b). Law 21/ 2013 on environmental assessment. Available from: https:/ / www.boe.es/boe/dias/2013/12/1 
1/pdfs / BOE-A-2013-12913.pdf (accessed 2 October 2017).

Official State Gazette (2015). Law 8/2015 on tax and non-tax measures in respect of the exploration, research and exploitation of hydrocarbons. Available from: https: / / www.boe.es/boe/dias/2015/05/2

2/pdfs/BOE-A-2015-5633.pdf (accessed 2 October 2017). 